DOI: $10.17805 /$ trudy.2019.1.5

\title{
ОПЫТНАЯ ПСИХОЛОГИЧЕСКАЯ ЛАБОРАТОРИЯ АКАДЕМИИ ГЕНЕРАЛЬНОГО ШТАБА РККА КАК ПРОТОТИП ПСИХОЛОГИЧЕСКОЙ СЛУЖБЫ ВООРУЖЕННЫХ СИЛ РОССИЙСКОЙ ФЕДЕРАЦИИ
}

\author{
И. А. Дьячук \\ Военная академия Генерального штаба Вооруженных Сил \\ Российской Федерации
}

Аннотация: Статья посвящена созданию опытной психологической лаборатории, ставшей первым в истории российской армии спещиализированным подразделением военных психологов.

По материалам научного доклада на конференции «Кросс-культурные и междисциплинарные исследования в истории психологии: результаты и перспективы» (Москва, 24-25 ноября 2018 г.), проведенной в рамках проекта № 18-513-18017, поддержанного РФФИ.

Ключевые слова: военная психология; психологическая служба; профессиональный психологический отбор; психологические исследования; опытная психологическая лаборатория; Академия Генерального штаба РККА

\section{EXPERIMENTAL PSYCHOLOGICAL LABORATORY OF THE ACADEMY OF THE GENERAL STAFF OF THE RED ARMY AS A PROTOTYPE OF THE PSYCHOLOGICAL SERVICE IN THE RUSSIAN ARMED FORCES}

\author{
I. A. Dyachuk \\ Military Academy of the General Staff of the Armed Forces \\ of the Russian Federation
}

Abstract: The paper is dedicated to the creation of the experimental psychologicallaboratory, becoming the first special military psychological unit in the history of the Russian Army.

The research is based on the materials of the scientific reportat the conference "Cross-Cultural and Interdisciplinary Studies into the History of Psychology: Results and Prospects" (Moscow, 24-25 November 2018), held within the project No. 18-513-18017 supported by RFBR.

Keywords: military psychology; psychological service; professional psychological selection; psychological research; experimental psychological laboratory; Academy of the General Staff of the Red Army

Изучение архивных документов и литературных источников, охватывающих годы образования и становления Академии Генерального штаба Рабоче-Крестьянской Красной Армии, впоследствии переименованной в Военную академию РККА имени М. В. Фрунзе (в период от 1918 г. до 30-х годов XX в.), позволяет проанализировать развитие военно-психологических идей и теорий в рамках исследования деятельности первого в российской армии профессионального подразделения специалистов-психологов.

Опытная психологическая лаборатория при Академии Генерального 
Научные труды Московского гуманитарного университета 2019 № 1

штаба РККА была создана 2 марта 1920 г. приказом Реввоенсовета Республики № 340. Инициатором ее учреждения стал Председатель Реввоенсовета Республики Л. Д. Троцкий. Одновременно с этим были утверждены Положение и Штат лаборатории (Российский государственный военный архив — РГВА. Ф. 4. Оп. 12. Д. 9).

Целью создания опытной психологической лаборатории стал «научно психологический анализ отдельных лиц и коллективов (военнослужащих и воинских частей), практическая работа по определению их годности и приспособленности, по определению средних типов и т. п., путем уже имеющихся в науке методов, а также с целью развития, применения в более широком масштабе, переработки и создания новых методов психологического исследования» (там же).

Штатом лаборатории предусматривалось 20 должностей, из них ученый состав (заведующий, помощники заведующего, лаборанты, статистик, счетчики) - 15 чел., административный состав (делопроизводитель, стенографист, переписчик, курьеры) -5 чел.

Подбор сотрудников лаборатории осуществлялся с учетом имеющихся у кандидатов соответствующей квалификации и опыта работы (военной службы). Определялось, что заведующий лабораторией назначается начальником академии из лиц, «обладающих полным знакомством и опытом в деле психологического исследования и достаточным военно-образовательным цензом» (там же).

В помощь заведующему лабораторией начальником академии назначались два помощника: «один, имеющий специально психологические познания, другой, из лиц, имеющих среднее военное образование» (там же). Остальной состав опытной психологической лаборатории назначался начальником академии, по представлению заведующего лабораторией.

Первыми сотрудниками назначены: заведующий лабораторией $-\mathrm{Ce}-$ галов Тимофей Ефимович, помощники заведующего - Рыбников Николай Александрович, Павловский Филипп Григорьевич, лаборанты - Жинкин Николай Иванович, Виноградов Константин Александрович, Ферстер Наталья Павловна и др.

В отчете об итогах работы академии от 17 сентября 1920 г. указывается, что сотрудниками лаборатории были проведены исследования со слушателями «на зрительные и слуховые восприятия, творческие ассоциации, а также реконструкцию» (РГВА. Ф. 11. Оп. 1. Д. 186).

Вместе с этим велась работа по следующим направлениям:

- разработка «психологических и педагогических основоположений военно-трудового перевоспитания морально дефективных и социально-науродованных подростков по идее милитаризации воспитания»; 


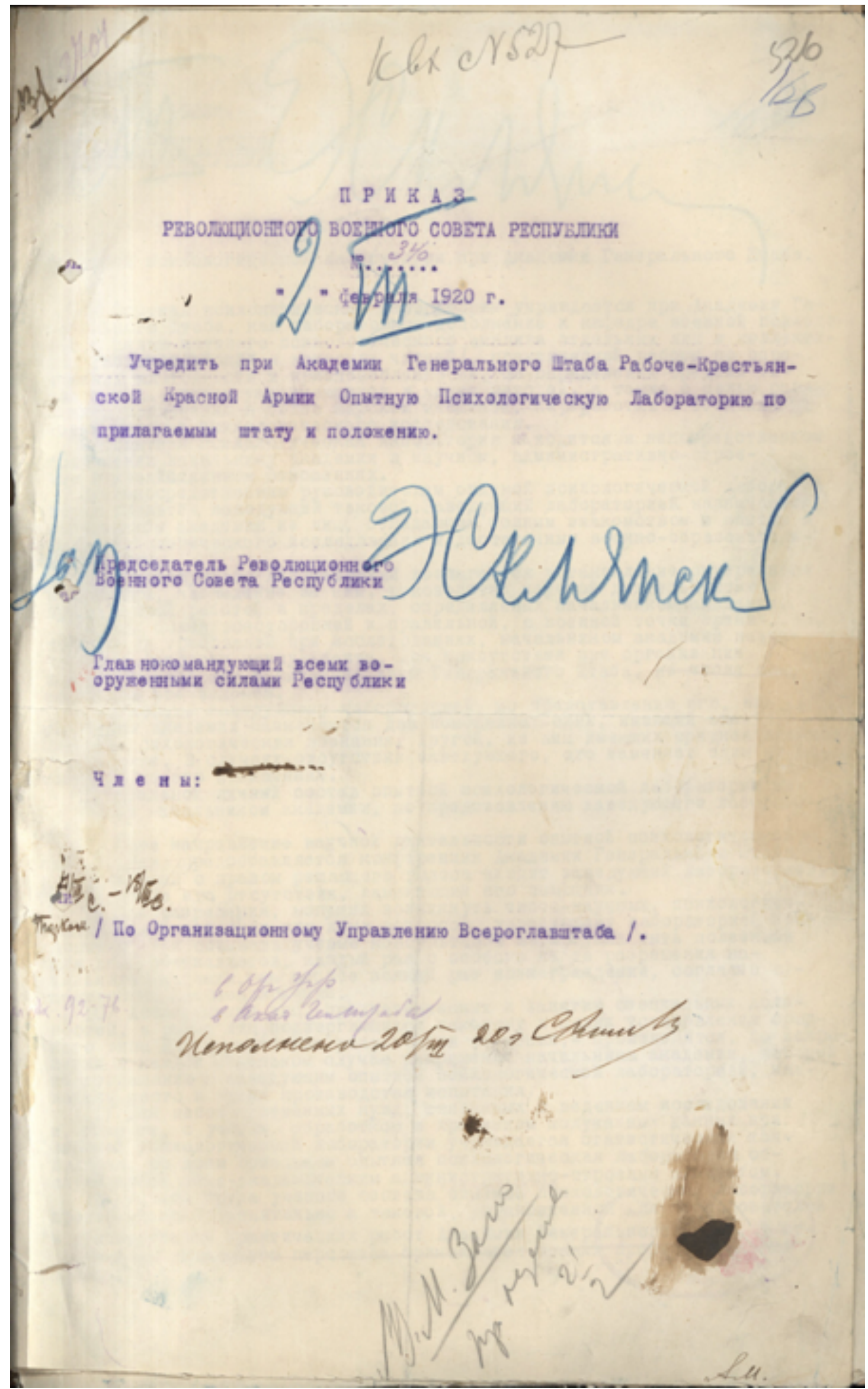




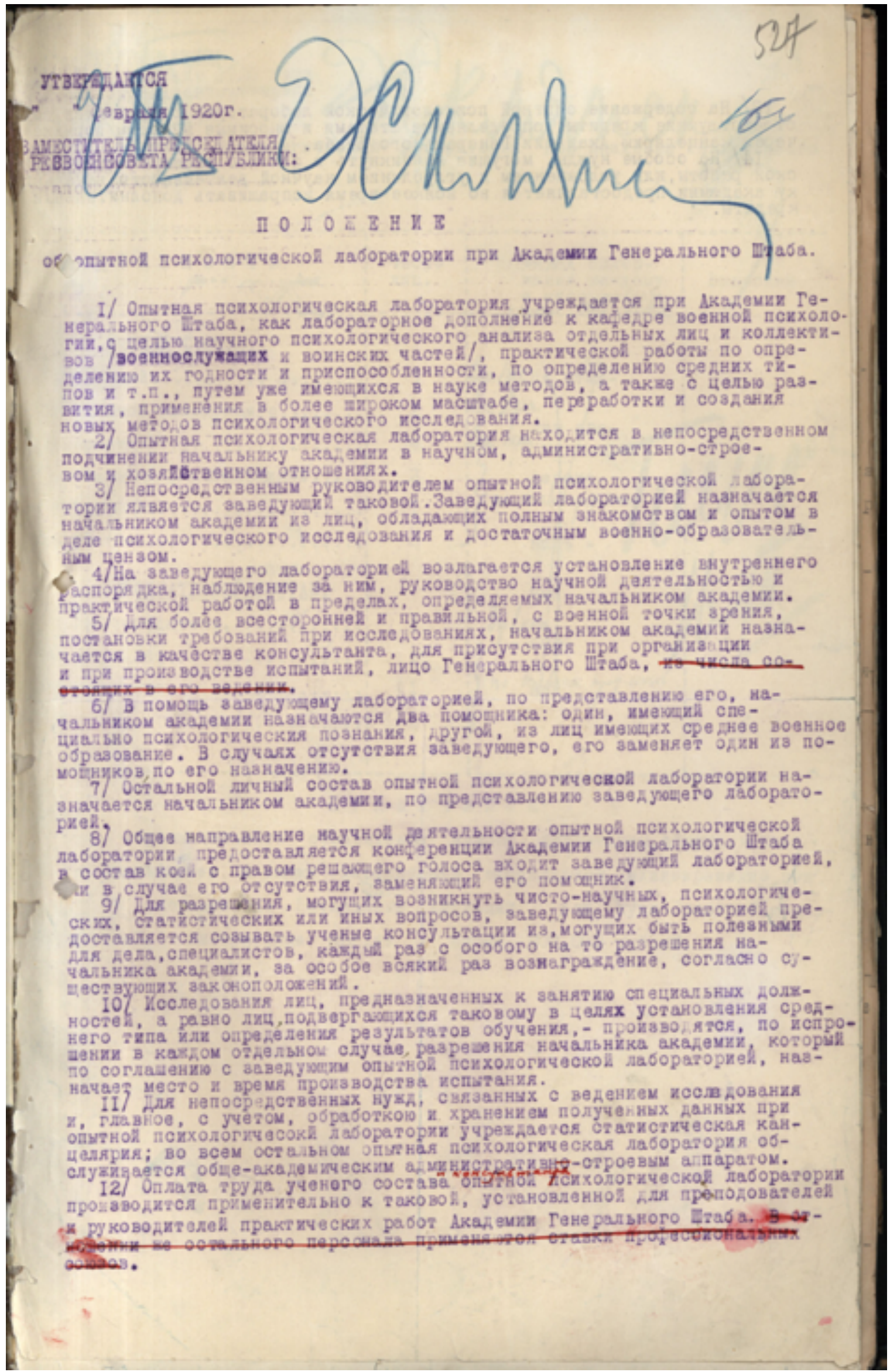


• издание «программ лекций и занятий по психологии, применительно к военной педагогике для окружных курсов и инструкторов Всевобуча»;

- «составление и обработка анкеты о читательских интересах красноармейцев»;

- «сбор революционных, политических плакатов агитационного характера, а также и пропагандистского, для экспериментальной психологической их оценки с точки зрения замечаемости и запоминаемости»;

- анкетирование «лиц прежнего и нового командного состава о недочетах и свойствах вождя вообще и военного вождя-командира - в частности»;

- «экспериментальная постановка индивидуального отбора лиц, таящих в себе задатки военного тактического руководителя-командира»;

- подготовка «инструментария и выработка методики опытного исследования звуковой команды (голос) и ее влияния на невыполнение приказа» (там же).

Для проведения внешних экспертиз научных трудов, привлечение к исследованиям экспертов сторонних организаций, заведующему лабораторией предоставлялось право «созывать ученые консультации, из могущих быть полезными для дела специалистов, каждый раз с особого на то разрешения начальника академии за особое вознаграждение, согласно существующих законоположений» (РГВА. Ф. 4. Оп. 12. Д. 9).

Самим же сотрудникам лаборатории оплата труда производилась в соответствии с установленными размерами заработной платы для преподавателей и руководителей практических работ академии.

В распоряжении лаборатории были выделены три комнаты в одной из квартир во дворе, где размещалась академия (из которых одна была проходной). Библиотечный фонд пополнялся путем закупки специализированной литературы, также закупались исследовательские инструменты и приборы, мебель (столы, шкафы, стулья).

Вместе с тем отмечается, что «крайняя бедность помещения и оборудования сильно отражается на успешности работы. Однако есть надежды осуществить взятые на себя задачи благодаря благожелательному отношению предреввоенсовета Республики [Л. Д. Троцкий] и его заместителя [Э. М. Склянский], который изъявил желание получать периодические доклады о ходе работ» (там же).

Таким образом, можно сделать вывод, что опытная психологическая лаборатория Академии Генерального штаба РККА, состоящая из психологов, медиков и других специалистов-исследователей, выполняющая задачи по профессиональному психологическому отбору и психологическому сопровождению слушателей, а так же проведению исследований в области 
военной психологии, является первым в истории российской армии специализированным подразделением военных психологов, прототипом ныне функционирующей психологической службы Вооруженных Сил Российской Федерации.

Данное исследование не закончено, в настоящий момент оно продолжается путем поиска в архивах, литературных источниках документального подтверждения результатов деятельности опытной психологической лаборатории, а так же жизненного пути и научного наследия ее сотрудников.

Дата поступления: 15.01.2018 г.

Дьячук Игорь Алексеевич - кандидат социологических наук, доцент, старший научный сотрудник научно-практического центра Военной академии Генерального штаба Вооруженных Сил Российской Федерации. Адрес: 119571, Россия, г. Москва, пр-т Вернадского, д. 100. Тел.: +7 (909) 697-64-65. Эл. адрес: Dyachyk@rambler.ru

Dyachuk Igor Alekseyevich, Candidate of Sociology, Associate Professor, Senior Research Fellow, Scientific and Practical Center, Military Academy of the General Staff of the Russian Federation. Postal address: 100, Vernadskogo Ave., Moscow, Russian Federation, 119571. Tel.: +7 (909) 697-64-65. E-mail: Dyachyk@ rambler.ru

\section{Для цитирования:}

Дьячук И. А. Опытная психологическая лаборатория Академии Генерального штаба РККА как прототип психологической службы Вооруженных Сил Российской Федерации [Электронный ресурс] // Научные труды Московского гуманитарного университета. 2019. № 1. URL: http://journals.mosgu.ru/trudy/article/view/932 (дата обращения: дд.мм. гг.). DOI: $10.17805 /$ trudy.2019.1.5 